\title{
Mieszana postać śluzowego raka piersi w materiale Krakowskiego Oddziału Centrum Onkologii — obraz kliniczny i wyniki leczenia u chorych leczonych w okresie 1975-2005
}

\author{
Piotr Skotnicki ${ }^{1}$, Łukasz Strzępek ${ }^{2}$, Beata Sas-Korczyńska ${ }^{3}$, \\ Marian Reinfuss ${ }^{4}$, Tomasz Walasek ${ }^{4}$, Anna Patla ${ }^{4}$
}

\begin{abstract}
Wstęp. Śluzowy rak piersi (mucinous breast carcinoma - MBC) stanowi 2\%-3\% wszystkich nowotworów złośliwych piersi i częstość jego występowania związana jest z wiekiem. Celem pracy jest charakterystyka kliniczno-patologiczna oraz ocena skuteczności leczenia u chorych na mieszaną postać śluzowego raka piersi (M-MBC).

Materiał i metody. Analizą objęto grupę 50 chorych na M-MBC leczonych w latach 1975-2005. Średni wiek chorych wynosił 64 lata, u 86\% chorych stwierdzono I-II stopień zaawansowania klinicznego, u 26\% chorych stwierdzono zajęcie węzłów chłonnych, a u 70\% obecna była ekspresja receptorów hormonalnych. U $43(86,0 \%)$ chorych wykonano radykalne odjęcie piersi, a u 7 (14,0\%) - tumorektomię z limfadenektomią pachową. Pooperacyjną radioterapię zastosowano u 24 chorych (48\%), a u 13 (26\%) - chemioterapię.

Wyniki. Bezobjawowe przeżycia 10-letnie uzyskano u 64\% chorych. Wyniki analiz jedno- i wielocechowej wykazały, że niezależnym istotnym czynnikiem prognostycznym był stan węzłów chłonnych pachowych (pN). Odsetki 10-letnich przeżyć bez objawów nowotworu wynosiły $81,1 \%$ (dla pN0) i 15,4\% (pN+). W okresie obserwacji przerzuty odległe wystąpiły u 16 chorych (32\%).

Wnioski. Obraz kliniczny M-MBC charakteryzuje: wysoki odsetek chorych z niezaawansowanym procesem nowotworowym oraz obecnością dodatnich receptorów hormonalnych i stosunkowo niski odsetek chorych z przerzutami do węzłów chłonnych. Wyniki leczenia chorych z M-MBC są stosunkowo dobre, a podstawowym czynnikiem prognostycznym jest stan mikroskopowy węzłów chłonnych pachowych.
\end{abstract}

\section{Mixed variant of mucinous breast cancer seen in the Oncology Centre in Krakow: clinical characteristics and treatment results in patients treated 1975-2005}

Introduction. Mucinous breast carcinoma (MBC) accounts for approximately 2-3\% of all breast cancer types. The purpose of this study is to present the clinico-pathological characteristics and treatment results in patients treated for mixed variant of $M B C$.

Material and methods. We analysed 50 patients with M-MBC treated between 1975 and 2005. The mean age was 64 years, and $86 \%$ patients presented with stage I or II breast cancer, involved lymph nodes were observed in $26 \%$, and hormonal receptors positivity was found in $70 \%$ cases. All patients received surgical treatment: mastectomy $(43-86 \%)$ or breast-conserving therapy $(7-14 \%)$. The adiuvant treatment consisted of radiotherapy $(24-48 \%)$, chemotherapy $(13-26 \%)$.

Results. The 10-year disease-free survival (DFS) rate was $64 \%$. Univariate and multivariate analyses showed that an independent statistically significant prognostic factor was the microscopic status of axillary lymph nodes (pN).

${ }^{1}$ Oddział Chirurgiczny Zabiegowy, Szpital im. św. Rafała w Krakowie

${ }^{2}$ Oddział Chirurgii Ogólnej i Urazowej, Szpital w Bochni

${ }^{3}$ Klinika Onkologii, Centrum Onkologii — Instytut im. Marii Skłodowskiej-Curie, Oddział w Krakowie

${ }^{4}$ Zakład Radioterapii, Centrum Onkologii — Instytut im. Marii Skłodowskiej-Curie, Oddział w Krakowie 
10-year DFS according to $\mathrm{pN}$ was $81.1 \%$ for $\mathrm{pN} 0$ and $15.4 \%$ for $\mathrm{pN}+$. During the follow-up 16 patients (32\%) developed distant metastases.

Conclusions. $\mathrm{M}-\mathrm{MBC}$ is characterised by the following: high ratio of lower stage disease, hormonal receptors positivity and relatively lower incidence of involved axillary lymph nodes.

NOWOTWORY J Oncol 2016; 66, 2: 97-102

Słowa kluczowe: śluzowy rak piersi, postać mieszana, przerzuty do węzłów chłonnych

Key words: mucinous breast cancer, mixed mucinous carcinoma, lymph node metastases

\section{Wstęp}

Śluzowy rak piersi (mucinous breast carcinoma - MBC) stanowi 2\%-3\% wszystkich złośliwych nowotworów piersi. Częstość jego występowania związana jest z wiekiem: u kobiet poniżej 35 roku życia wynosi 1\%, natomiast u kobiet powyżej 75 roku życia sięga 7\% [1-10].

Zgodnie z definicją Światowej Organizacji Zdrowia (World Health Organization - WHO) MBC jest nowotworem, który charakteryzuje się skupiskiem przeważnie małych, jednorodnych komórek pływających w dużej ilości pozakomórkowego śluzu [1]. Wyróżniane są dwie postacie MBC: czysta (pure MBC — P-MBC) i mieszana (mixed MBC $M-M B C)$. Do P-MBC zaliczane są guzy w całości zbudowane z gniazd komórek nowotworowych „pływających” w obfitym pozakomórkowym śluzie, natomiast w M-MBC spotykane są dodatkowo obszary o budowie przewodowego raka naciekającego (invasive ductal carcinoma - IDC), pozbawionego pozakomórkowego śluzu [1, 8, 11-13]. Tak zwane wysepki raka śluzowego stanowią ponad $90 \%$ masy guza w P-MBC i 50\%-89\% w M-MBC $[1,8,13]$.

W odróżnieniu od IDC, MBC charakteryzuje się stosunkowo wolnym przebiegiem klinicznym, obecnością ekspresji receptorów estrogenowych (ponad 90\%), progesteronowych (70\%-80\%), brakiem amplifikacji białka HER2, wysokim odsetkiem chorych (85\%-90\%) bez przerzutów do węzłów chłonnych pachowych i dobrym rokowaniem (wieloletnie przeżycia przekraczają 80\%). MBC jest zaliczany do grupy tzw. „dobrze rokujących" postaci raka piersi [1-3, 5-17]. Należy jednak zwrócić uwagę, że przedstawione powyżej cechy $M B C$ dotyczą przede wszystkim chorych na P-MBC i w znacznie mniejszym stopniu — chorych na M-MBC, gdzie obserwowany jest niższy odsetek chorych bez przerzutów do węzłów chłonnych pachowych oraz mniejszy odsetek wieloletnich przeżyć [2, 3, 5, 6, 8-10, 18-22].

Rzadkość występowania MBC powoduje, że prezentowane w piśmiennictwie grupy chorych zazwyczaj nie przekraczają kilkudziesięciu przypadków; poza tym część autorów przedstawia materiały kliniczne obejmujące zarówno P-MBC, jak i M-MBC, część zaś wyłącznie P-MBC. Analiza piśmiennictwa wykazuje, że zasadniczo wiemy więcej o P-MBC, gdzie liczba publikacji jest wyraźnie wyższa, a znacznie mniej o M-MBC, gdzie jest ona znacząco niż- sza. Ponadto niektórzy badacze, analizując obraz kliniczny i wyniki leczenia, sugerują, że M-MBC jest bliższy IDC aniżeli MBC. Z kolei inni uważają, że do MBC powinien być zaliczany wyłącznie P-MBC [7-9, 18, 19, 23-25].

Celem pracy jest przedstawienie charakterystyki populacyjno-klinicznej z uwzględnieniem wybranych parametrów histologicznych i biologicznych markerów w grupie chorych na M-MBC oraz ocena skuteczności leczenia tych chorych.

\section{Materiał i metody}

Analizą objęto jest grupę 50 chorych na M-MBC leczonych w Krakowskim Oddziale Centrum Onkologii — Instytutu im. Marii Skłodowskiej-Curie w latach 1975-2005. Stanowili oni $0,5 \%$ wszystkich (11 001) chorych leczonych $z$ powodu raka piersi $w$ tym okresie.

Charakterystyka omawianej grupy została przedstawiona w tabeli I.

Wiek chorych wahał się od 37 do 78 lat i wynosił średnio 64 lata (wartość mediany: 65 lat). Zdecydowana większość (37/50 - 74\%) była powyżej 60 roku życia. Zaledwie w 3 przypadkach (6\%) nowotwór został wykryty w czasie badania przesiewowego, natomiast u pozostałych 47 chorych (94\%) objawy kliniczne obecności guza w piersi utrzymywały się od 1 do 16 miesięcy (średnia: 3,4 miesiąca, mediana: 3,8 miesiąca).

U wszystkich chorych zaawansowanie nowotworu oceniano według klasyfikacji TNM obowiązujących w okresie, kiedy chore były leczone. Na potrzeby prezentowanej analizy, na podstawie danych pochodzących z posiadanej dokumentacji medycznej, dokonano ponownej oceny stopnia zaawansowania zgodnie z aktualnie obowiązującą klasyfikacją TNM [26].

U 86 \% chorych stwierdzono I-Il stopień zaawansowania nowotworu, z czego II stopień u 25 chorych (50\%). W ocenie wielkości guza (cecha pT) również dominowało małe zaawansowanie - u 44 (89\%) chorych guz w piersi miał średnicę poniżej $5 \mathrm{~cm}$, przy czym guzy mniejsze (poniżej $2 \mathrm{~cm}$ ) obecne były u 21 (43\%) chorych. Ocena stanu węzłów chłonnych pachowych (pN) wykazała, że przerzuty były obecne u 13 chorych (26\%), w tym zajęcie 1-3 węzłów stwierdzono u 5 (10,0\%) chorych, a ponad 4 węzłów - u $8(16,0 \%)$ chorych. Badanie immunohistochemiczne wykazało ekspresję receptorów: estrogenowego (ER) i progesteronowego (PgR) u 35 (70,0\%) chorych. 
Tabela I. Charakterystyka kliniczna i patologiczna grupy 50 chorych na mieszaną postać śluzowego raka piersi (M-MBC)

\begin{tabular}{|c|c|c|}
\hline Czynnik & $\begin{array}{l}\text { Liczba } \\
\text { chorych }\end{array}$ & $\%$ \\
\hline \multicolumn{3}{|l|}{ Wiek: } \\
\hline$\leq 60$ lat & 13 & 26,0 \\
\hline$>60$ lat & 37 & 74,0 \\
\hline \multicolumn{3}{|l|}{ Czas trwania objawów chorobowych: } \\
\hline$<5$ miesięcy & 20 & 40,0 \\
\hline$\geq 5$ miesięcy & 27 & 54,0 \\
\hline guz wykryty w badaniach profilaktycznych & 3 & 6,0 \\
\hline \multicolumn{3}{|l|}{ Stopień zaawansowania: } \\
\hline 1 & 18 & 36,0 \\
\hline ॥ & 25 & 50,0 \\
\hline III A & 7 & 14,0 \\
\hline \multicolumn{3}{|l|}{ Wielkość guza (pT): } \\
\hline$<2 \mathrm{~cm}$ & 21 & 42,0 \\
\hline $2-5 \mathrm{~cm}$ & 23 & 46,0 \\
\hline$>5 \mathrm{~cm}$ & 6 & 12,0 \\
\hline \multicolumn{3}{|l|}{ Stan węzłów chłonnych pachowych (pN): } \\
\hline pNO & 37 & 74,0 \\
\hline pN1a & 5 & 10,0 \\
\hline $\mathrm{pN} 2 \mathrm{a}$ & 8 & 16,0 \\
\hline \multicolumn{3}{|l|}{ Ekspresja receptora estrogenowego: } \\
\hline obecna & 35 & 70,0 \\
\hline nieobecna & 5 & 10,0 \\
\hline brak danych & 10 & 20,0 \\
\hline \multicolumn{3}{|l|}{ Ekspresja receptora progesteronowego: } \\
\hline obecny & 35 & 70,0 \\
\hline nieobecny & 6 & 12,0 \\
\hline brak danych & 9 & 18,0 \\
\hline \multicolumn{3}{|l|}{ Zakres leczenia chirurgicznego: } \\
\hline radykalne odjęcie piersi & 43 & 86,0 \\
\hline leczenie oszczędzające pierś & 7 & 14,0 \\
\hline Razem & 50 & 100,0 \\
\hline
\end{tabular}

Wszystkie chore były pierwotnie leczone operacyjnie. U 43 (86\%) chorych wykonano radykalne odjęcie piersi (mastektomię), w tym u 15 (30,0\%) metodą Halsteda (chore leczone w latach 1975-1986), a u 28 (56,0\%) metodą Pateya lub Madena. W latach 1995-2005 u 7 (14,0\%) chorych przeprowadzono leczenie oszczędzające (tumorektomia z limfadenektomią pachową w skojarzeniu z radioterapią).

Pooperacyjna radioterapia, w warunkach teleradioterapii, zastosowana została u 24 chorych (48\%): u 7 (14\%) jako składowa leczenia oszczędzającego, a u pozostałych 17 (34\%) — po mastektomii.W przypadku leczenia oszczędzającego w czasie radioterapii wiązką fotonową napromieniano całą pierś, stosując technikę wiązek tangencjalnych, podając dawkę 50 Gy w 25 frakcjach w czasie 5 tygodni. Następnie podwyższano dawkę na lożę po usuniętym guzie (tzw. boost) o 10 Gy podanych w 5 frakcjach z wykorzystaniem wiązki elektronowej. W przypadku radioterapii stosowanej po mastektomii wskazaniami do takiego postępowania były: obecność przerzutów w węzłach chłonnych pachowych i/lub wielkość guza w piersi przekraczająca $5 \mathrm{~cm}$ średnicy. Obszar napromieniany obejmował ścianę klatki piersiowej wraz z blizną pooperacyjną oraz regionalne węzły chłonne (pachowe, przymostkowe, podobojczykowe, nadobojczykowe). Radioterapię realizowano z użyciem wiązki fotonowej (kobalt 60 lub fotony 6-9MV) oraz wiązki elektronowej, podając dawkę 50 Gy w 25 frakcjach w czasie 5 tygodni.

Leczenie systemowe prowadzono u 13 (26,0\%) chorych z obecnością przerzutów w węzłach chłonnych pachowych, zastosowano 6 cykli chemioterapii według schematu CMF (endoksan, 5-fluorouracyl, metotreksat), po której wdrażano hormonoterapię tamoksyfenem.

Za kryterium oceny skuteczności leczenia przyjęto 10-letnie przeżycie bez objawów nowotworu, licząc od daty wykonania zabiegu operacyjnego. Wszystkie chore obserwowane były przynajmniej przez 10 lat, o ile wcześniej nie nastąpił zgon. Średni czas obserwacji wyniósł 15 lat (10-40 lat). Prawdopodobieństwo przeżycia 10 lat oszacowano metodą Kaplana-Meiera, a dla oceny stwierdzonych w materiale różnic posłużono się testem log-rank wg Peto i wsp. Do oceny wpływu wybranych czynników na przeżycia chorych posłużono się modelem proporcjonalnego hazardu Coxa. We wszystkich testach statystycznych przyjęto za poziom znamienności statystycznej $\mathrm{p} \leq 0,05$.

\section{Wyniki}

W badanej grupie chorych na M-MBC 10-letnie przeżycia bez objawów nowotworu wynosiło 64\%. Na rycinie 1

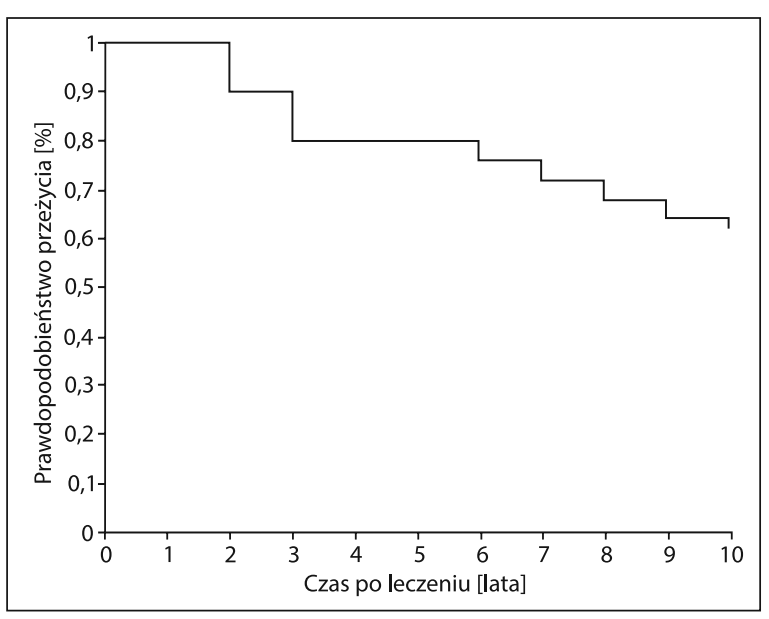

Rycina 1. Krzywa prawdopodobieństwa przeżycia bez objawów nowotworu w grupie 50 chorych na mieszaną postać śluzowego raka piersi M-MBC 
Tabela II. Wyniki analizy wpływu czynników populacyjnych, klinicznych, mikroskopowych oraz zakresu leczenia chirurgicznego na wyniki leczenia

\begin{tabular}{|c|c|c|c|c|}
\hline \multirow[t]{2}{*}{ Czynnik } & \multirow[t]{2}{*}{ Liczba chorych leczonych } & \multicolumn{2}{|c|}{ 10-letnie przeżycia bezobjawowe } & \multirow{2}{*}{$\begin{array}{c}\mathrm{p} \\
\text { (test log-rank) }\end{array}$} \\
\hline & & $\begin{array}{l}\text { Liczba } \\
\text { chorych }\end{array}$ & $\%$ & \\
\hline \multicolumn{5}{|l|}{ Wiek: } \\
\hline$\leq 60$ lat & 13 & 9 & 69,2 & N.S. \\
\hline$>60$ lat & 37 & 23 & 62,2 & \\
\hline \multicolumn{5}{|l|}{ Czas trwania objawów chorobowych: } \\
\hline$<5$ miesięcy & 20 & 13 & 65,0 & N.S. \\
\hline$\geq 5$ miesięcy & 27 & 17 & 62,9 & \\
\hline guz wykryty w badaniach profilaktycznych & 3 & 2 & 66,7 & \\
\hline \multicolumn{5}{|l|}{ Stopień zaawansowania: } \\
\hline I & 18 & 12 & 66,7 & N.S. \\
\hline ॥ & 25 & 17 & 68,0 & \\
\hline III A & 7 & 3 & 42,9 & \\
\hline \multicolumn{5}{|l|}{ Wielkość guza (pT): } \\
\hline$<2 \mathrm{~cm}$ & 21 & 14 & 66,7 & N.S. \\
\hline $2-5 \mathrm{~cm}$ & 23 & 14 & 60,8 & \\
\hline$>5 \mathrm{~cm}$ & 6 & 4 & 66,7 & \\
\hline \multicolumn{5}{|l|}{ Stan węzłów chłonnych (pN): } \\
\hline pNO & 37 & 30 & 81,1 & $p<0,01$ \\
\hline pN1a & 5 & 2 & 40,0 & \\
\hline pN2a & 8 & 0 & - & \\
\hline \multicolumn{5}{|l|}{ Ekspresja receptora estrogenowego: } \\
\hline obecna & 35 & 23 & 65,7 & N.S. \\
\hline nieobecna & 5 & 3 & 60,0 & \\
\hline brak danych & 10 & 6 & 60,0 & \\
\hline \multicolumn{5}{|l|}{ Ekspresja receptora progesteronowego: } \\
\hline obecna & 35 & 24 & 69,6 & N.S. \\
\hline nieobecna & 6 & 3 & 50,0 & \\
\hline brak danych & 9 & 5 & 55,6 & \\
\hline \multicolumn{5}{|l|}{ Zakres leczenia chirurgicznego: } \\
\hline radykalne odjęcie piersi & 43 & 27 & 62,8 & N.S. \\
\hline leczenie oszczędzające & 7 & 5 & 71,4 & \\
\hline Razem & 50 & 32 & 64,0 & - \\
\hline
\end{tabular}

N.S. - non significant (różnice statystycznie nieistotne, $p>0,05$ )

przedstawiono krzywą prawdopodobieństwa przeżycia bez objawów nowotworu, a w tabeli ll zestawiono wyniki analizy wpływu badanych czynników na wyniki leczenia u chorych na M-MBC.

Jedynym statystycznie istotnym czynnikiem prognostycznym w badanej grupie chorych okazał się stan węzłów chłonnych pachowych (pN). Odsetki 10-letniego przeżycia w zależności od tego czynnika wynosiły: $81,1 \%$ vs $15,4 \%$ odpowiednio w przypadku braku vs obecności przerzutów w węzłach ( $p<0,01$, test long rank). Różnice te obrazuje rycina 2.
Powyższe obserwacje potwierdzone zostały przez wyniki wielocechowej analizy przeprowadzonej metodą Coxa. Stan węzłów chłonnych pachowych okazał się być niezależnym czynnikiem prognostycznym (ryzyko względne 3,12 dla 95\% przedziału ufności: 1,78-5,12, dla $\mathrm{p}=0,001$ ).

W tabeli III zestawiono wyniki obserwacji chorych prowadzonej po zakończeniu leczenia.

Spośród wszystkich 50 chorych, w czasie obserwacji 18 chorych (36\%) zmarło. U 16 (32\%) z nich przyczyną zgonu było niepowodzenie w leczeniu raka piersi, którym był rozwój przerzutów odległych. Zlokalizowane one były głównie 


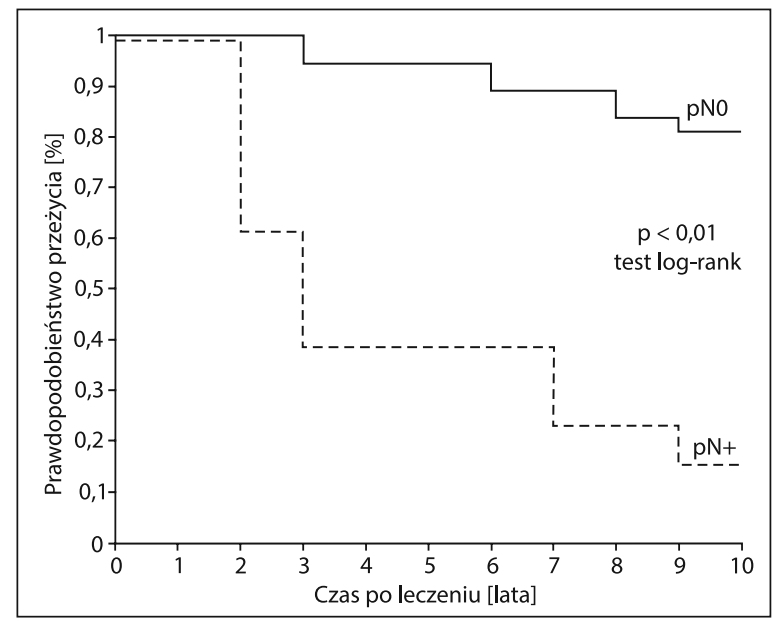

Rycina 2. Krzywe prawdopodobieństwa przeżycia bez objawów nowotworu w zależności od stanu węzłów chłonnych (pN)

Tabela III. Obserwacja po leczeniu badanej grupy

\begin{tabular}{lcc}
\hline Zdarzenie & Liczba chorych & $\%$ \\
\hline Przeżycie 10 lat bez objawów nowotworu & 32 & 64,0 \\
Zgony & 18 & 36,0 \\
Przyczyny zgonu: & & \\
M-MBC: & 15 & 30,0 \\
$\quad$ przerzuty odległe & 1 & 2,0 \\
$\quad$ przerzuty i wznowy lokoregionalne & 2 & 4,0 \\
inne przyczyny & 50 & 100,0 \\
\hline Razem &
\end{tabular}

w kościach, mózgu, płucach lub wątrobie. U jednej chorej wystąpieniu przerzutów odległych towarzyszyła rozległa wznowa lokoregionalna; chora ta zmarła w 4. roku po leczeniu chirurgicznym; pierwotnie stwierdzano u niej guz w piersi o średnicy $8 \mathrm{~cm}$, czemu towarzyszyły liczne przerzuty w węzłach chłonnych pachowych.

Dwie chore badanej grupy $(4,0 \%)$ zmarły bez objawów nowotworu (odpowiednio w 2. i 3. roku po leczeniu) z powodu wylewu krwi do mózgu.

\section{Dyskusja}

Przeprowadzona analiza grupy 50 chorych na M- MBC leczonych w Krakowskim Oddziale Centrum Onkologii pozwoliła na określenie charakterystycznych cech, do których zaliczają się: wiek (średni: 64 lata), niski stopień zaawansowania klinicznego (86\% w stopniu I-II) i patologicznego (pT1-2 u 88\%, pN0 u 74\%), ekspresja receptorów: estrogenowego i progesteronowego (70\%). Podobne cechy wymieniane są w piśmiennictwie dotyczącym M-MBC $[2,3,5$, 6, 8-10, 18-22].

Wyniki własne wskazują na istotne znaczenie prognostyczne stanu węzłów chłonnych. Przerzuty w węzłach
Tabela IV. Częstość przerzutów do węzłów chłonnych pachowych $u$ chorych na M-MBC

\begin{tabular}{lc}
\hline $\begin{array}{l}\text { Autorzy [pozycja piśmiennictwa], } \\
\text { rok publikacji }\end{array}$ & $\begin{array}{c}\text { \% chorych z obecnością } \\
\text { przerzutów do węzłów } \\
\text { chłonnych pachowych (pN+) }\end{array}$ \\
\hline Rasmussen [19], 1995 & $33 \%$ \\
Komaki i wsp. [18], 1988 & $46 \%$ \\
Scopsi i wsp. [20], 1994 & $65 \%$ \\
André i wsp. [21], 1995 & $41 \%$ \\
Fentiman i wsp. [2], 1997 & $46 \%$ \\
Anan i wsp. [9], 2001 & $33 \%$ \\
Paramo i wsp. [22], 2002 & $29 \%$ \\
Ranade i wsp. [5], 2010 & $39 \%$ \\
Bae i wsp. [27], 2011 & $53 \%$ \\
Kashiwagi i wsp. [8], 2013 & $17 \%$ \\
Skotnicki i wsp. & $26 \%$ \\
prezentowane wyniki własne 2015 & \\
\hline
\end{tabular}

Tabela V. Wyniki leczenia (przeżycie bez objawów nowotworu) chorych na M-MBC

\begin{tabular}{lc}
\hline $\begin{array}{l}\text { Autorzy, [pozycja piśmiennictwa], } \\
\text { rok publikacji }\end{array}$ & $\begin{array}{c}\text { Przeżycia } \\
\text { bezobjawowe } \\
\text { 10-letnie }\end{array}$ \\
\hline Komaki i wsp. [18], 1989 & $66 \%$ \\
Toikkanen i Kujari [6], 1989 & $41 \%$ \\
Scopsi i wsp. [20], 1994 & $38 \% *$ \\
André i wsp. [21], 1995 & $20,3 \%$ \\
Fentiman i wsp. [2], 1997 & $54 \%$ \\
Cyrta i wsp. [3], 2013 & $64,7 \%$ \\
Kashiwagi i wsp. [8], 2013 & $59 \%$ \\
Skotnicki i wsp. & $64 \%$ \\
prezentowane wyniki własne 2015 & \\
\hline
\end{tabular}

*Przeżycie 20-letnie

chłonnych pachowych stwierdzono u $13(26,0 \%)$ chorych. W tabeli IV zestawiono, jak często ta cecha występuje w materiałach przedstawianych przez innych autorów.

Dane z piśmiennictwa wskazują, że przerzuty do węzłów chłonnych pachowych występują u $17 \%-65 \%$ chorych na M-MBC [2, 5, 8, 9, 18-22, 27-29].

Obserwacje własne wskazują, że 10-letnie przeżycie bez objawów nowotworu wynosi $64,0 \%$. W tabeli $V$ zestawiono wyniki własne z podawanymi w piśmiennictwie.

Dane z piśmiennictwa wykazują, że 10-letnie przeżycie bezobjawowe $u$ chorych na M-MBC waha się od $20 \%$ do $66 \%[2,3,6,8,18,20,21,25,30]$.

Wyniki analiz jedno- i wielocechowej wykazały, że jedynym niezależnym czynnikiem prognostycznym jest stan węzłów chłonnych ( $\mathrm{pN}$ ). Inni autorzy również zwracają uwagę na znaczenie prognostyczne tego czynnika [1, 5, 7-9, $18,21,28]$. 
Porównanie obserwacji własnych, przedstawionych w prezentowanej pracy i opublikowanych wcześniej (doty(zących P-MBC), z danymi piśmiennictwa wskazuje, że M-MBC jest jednak nowotworem o gorszym rokowaniu w porównaniu z P-MBC. Widoczne są różnice w częstości występowania przerzutów do węzłów chłonnych pachowych: 0\%-29\% w grupie chorych na P-MBC i 17\%-65\% w grupie chorych na M-MBC $[2,5,9,11,12,16-18,20-23,27,29-32]$. Podobne różnice stwierdzane są w odsetkach 10-letnich przeżyć bezobjawowych, które wynoszą 54\%-90\% (dla P-MBC) i 20\%-66\% (M-MBC) [2, 3, 6, 8, 11, 12, 16-18, 20, 21, 25, 27, 30-34].

\section{Wnioski}

Przeprowadzona analiza materiału klinicznego pozwala na sformułowanie następujących wniosków:

1) obraz kliniczny M-MBC charakteryzuje: niski stopień (I-II) zaawansowania klinicznego, ekspresja receptorów estrogenowego i progesteronowego oraz niski odsetek chorych z obecnością przerzutów raka w węzłach chłonnych pachowych,

2) wyniki leczenia chorych z M-MBC są stosunkowo dobre (10-letnie przeżycie bezobjawowe wynosi 64\%),

3) niezależnym istotnym czynnikiem prognostycznym jest stan węzłów chłonnych pachowych (pN).

\section{Konflikt interesów: nie zgłoszono}

\author{
Prof. nadzw. dr hab. med. Beata Sas-Korczyńska \\ Klinika Onkologii \\ Centrum Onkologii — Instytut im. Marii Skłodowskiej-Curie \\ Oddział w Krakowie \\ ul. Garncarska 11, 31-115 Kraków \\ e-mail:z5korczy@cyf-kr.edu.pl
}

Otrzymano: 22 czerwca 2015 r.

Przyjęto do druku: 4 sierpnia 2015 r.

\section{Piśmiennictwo}

1. Bussolati G, Sapino A. Mucinous carcinoma and carcinoma with signet-ring-cell differentiation. W: World Health Organization Classification of tumours. WHO. International Agency for Research on Cancer (IARC) $4^{\text {th }}$ ed. Lyon 2012; 60-61.

2. Fentiman IS, Millis RR, Smith P i wsp. Mucoid breast carcinomas: histology and prognosis. Br J Cancer 1997; 75: 1061-1065.

3. Cyrta J, Andreiuolo F, Azoulay S i wsp. Pure and mixed mucinous carcinoma of the breast: fine needle aspiration cytology findings and review of the literature. Cytopathology 2013; 24: 377-384

4. Skotnicki P. Effectiveness of surgical treatment and the analysis of prognostic factors in mucinous carcinoma of the breast. Nowotwory J Oncol 2001; 51: 467-78.

5. Ranade A, Batra R, Sandhu G i wsp. Clinicopathological evaluation of 100 cases of mucinous carcinoma of breast with emphasis on axillary staging and special reference to a micropapillary pattern. J Clin Pathol 2010; 63: 1043-1047.

6. Toikkanen S, Kujari H. Pure and mixed mucinous carcinomas of the breast: a clinicopathologic analysis of 61 cases with long-term follow-up. Hum Pathol 1989; 20: 758-764.

7. Lannigan AK, Going JJ, Weiler-Mithoff E i wsp. Mucinous breast carcinoma. Breast 2002; 11: 359-361.

8. Kashiwagi S, Onoda N, Asano Y i wsp. Clinical significance of the subclassification of 71 cases mucinous breast carcinoma. Springerplus 2013; 2 : 481-487
9. Anan K, Mitsuyama S, Tamae Ki wsp. Pathological features of mucinous carcinoma of the breast are favourable for breast-conserving therapy. Eur J Surg Oncol 2001; 27: 459-463.

10. Ha KY, Deleon P, Deleon W. Invasive mucinous carcinoma of the breast. Proc (Bayl Univ Med Cent) 2013; 26: 295-297.

11. Cao AY, He M, Liu ZB i wsp. Outcome of pure mucinous breast carcinoma compared to infiltrating ductal carcinoma: a population-based study from China. Ann Surg Oncol 2012; 19: 3019-3027.

12. Di Saverio S, Gutierrez J, Avisar E. A retrospective review with long term follow up of 11,400 cases of pure mucinous breast carcinoma. Breast Cancer Res Treat 2008; 111: 541-547.

13. Tan PH, Tse GM, Bay BH. Mucinous breast lesions: diagnostic challenges. J Clin Pathol 2008; 61: 11-19.

14. Yang $\mathrm{M}$, Li X, Chun-Hong $\mathrm{P}$ i wsp. Pure mucinous breast carcinoma: a favorable subtype. Breast Care (Basel) 2013; 8: 56-59.

15. Dragoumis DM, Assimaki AS, Tsiftsoglou AP. Pure mucinous carcinoma with axillary lymph node metastasis in a male breast. Breast Cancer 2012; 19: 365-368.

16. Morand C, Verrièle V, Valo I i wsp. Pure mucinous carcinomas of the breast: prognostic study including DNA flow cytometry. Cytometry Part $B$ (Clinical Cytometry) 2009; 76B: 56-62.

17. Sas-Korczyńska B, Mituś J, Stelmach A i wsp. Mucinous breast cancer - clinical characteristics and treatment results in patients treated at the Oncology Centre in Kraków between 1952 and 2002. Contemp Oncol (Pozn) 2014; 18: 120-123.

18. Komaki K, Sakamoto G, Sugano H i wsp. Mucinous carcinoma of the breast in Japan. A prognostic analysis based on morphologic features. Cancer 1988; 61: 989-996.

19. Rasmussen BB. Human mucinous breast carcinomas and their lymph node metastases. A histological review of 247 cases. Pathol Res Pract 1985; 180: 377-382.

20. Scopsi L, Andreola S, Pilotti S i wsp. Mucinous carcinoma of the breast. A clinicopathologic, histochemical, and immunocytochemical study with special reference to neuroendocrine differentiation. Am J Surg Pathol 1994; 18: 702-711.

21. André S, Cunha F, Bernardo M i wsp. Mucinous carcinoma of the breast: a pathologic study of 82 cases. J Surg Oncol 1995; 58: 162-167.

22. Paramo JC, Wilson C, Velarde D i wsp. Pure mucinous carcinoma of the breast: is axillary staging necessary? Ann Surg Oncol 2002; 9: $161-164$

23. Avisar E, Khan MA, Axelrod D i wsp. Pure mucinous carcinoma of the breast: a clinicopathologic correlation study. Ann Surg Oncol 1998; 5: 447-451.

24. Ucla L, Fenton J, Mathieu G i wsp. Cancer colloides du sein. Interet de la radiotherapie. Serie de 138 cas traites a I'Institute Curie. Bull Cancer 1988; 75: 783-787.

25. Laucirica R, Bentz JS, Khalbuss WE i wsp. Performance characteristics of mucinous (colloid) carcinoma of the breast in fine-needle aspirates: observations from the College of American Pathologists Interlaboratory Comparison Program in Nongynecologic Cytopathology. Arch Pathol Lab Med 2011; 135: 1533-1538.

26. Sobin L, Gospodarowicz M, Wittekind C. TNM. Klasyfikacja nowotworów złośliwych. Gdańsk: Via Medica, 2010, 143-151.

27. Bae SY, Choi MY, Cho DH i wsp. Mucinous carcinoma of the breast in comparison with invasive ductal carcinoma: clinicopathologic characteristics and prognosis. J Breast Cancer 2011; 14: 308-313.

28. Reimer T. Management of Rare Histological Types of Breast Tumours. Breast Care (Basel) 2008; 3: 190-196.

29. Wilson TE, Helvie MA, Oberman HA i wsp. Pure and mixed mucinous carcinoma of the breast: pathologic basis for differences in mammographic appearance. AJR Am J Roentgenol 1995; 165: 285-289.

30. Simpson JF, Page DL. Prognostic value of histopathology in the breast. Semin Oncol 1992; 19: 254-262.

31. Tan JZ, Waugh J, Kumar B i wsp. Mucinous carcinomas of the breast: imaging features and potential for misdiagnosis. J Med Imaging Radiat Oncol 2013; 57: 25-31.

32. Komenaka IK, El-Tamer MB, Troxel A i wsp. Pure mucinous carcinoma of the breast. Am J Surg 2004; 187: 528-532.

33. Vo $\mathrm{T}$, Xing $\mathrm{Y}$, Meric-Bernstam $\mathrm{F}$ i wsp. Long-term outcomes in patients with mucinous, medullary, tubular, and invasive ductal carcinomas after lumpectomy. Am J Surg 2007; 194: 527-531.

34. $\mathrm{LiCl}$. Risk of mortality by histologic type of breast cancer in the United States. Horm Cancer 2010; 1: 156-165. 